\title{
BLACK CRUSTS IN THE EUROPEAN BUILT ENVIRONMENT
}

\author{
C. Saiz-Jimenez and B. Hermosin \\ Instituto de Recursos Naturales y Agrobiologia, CSIC, \\ Apartado 1052, 41080 Sevilla, Spain
}

\section{CONTENTS}
Abstract
1. Introduction
2. Sources of organic pollutants in urban environments
2.1. Hydrocarbons
2.2. Acids and ketones
2.3. Triterpenoid hydrocarbons
2.4. Polycyclic aromatic hydrocarbons
2.5. Carbonaceous matter
2.6. Sites investigated
2.7. Solvent extraction of black crusts
3. Conclusions
4. Acknowledgements
5. References

\begin{abstract}
Buildings and monuments act as repositories of airborne organic pollutants, which accumulate at the surfaces in zones frequently soaked by rainwater but are not washed out. In these areas thick black crust deposits can be found, which contribute to soiling of stone surfaces. The exposed building materials act as a non-selective surface, passively entrapping all deposited airborne particulate matter and organic compounds, which obviously modifies the composition of the materials present in the stone surface. Black crusts from different European monuments and buildings contain molecular markers that are characteristic of petroleum derivatives.
\end{abstract}




\section{INTRODUCTION}

The Northern Hemisphere is experiencing a series of severe ecological problems with forest decline, acidification of lakes, and accelerated corrosion of monuments, buildings, and metallic structures.

Stone buildings, monuments, outdoors-exposed sculptures and objects of art have been degraded over the centuries by natural causes. Wind, rain, and frosts contribute to a gradual process of ageing and deterioration. The alteration of stone is not therefore a contemporary phenomenon, but was already known in ancient times, and was a cause of preoccupation to Greek and Roman writers.

The process of weathering of a rock begins as soon as it is taken from the quarry and comes into contact with atmospheric agents. However, in the last century, industrial and urban activities have modified the composition of the atmosphere, resulting in a more aggressive environment, accelerating the decay of materials.

Thousands of chemicals are emitted directly or indirectly to the atmosphere because of human activities. Once released into the atmosphere, organic and inorganic airborne pollutants may undergo a variety of complex interactions determined by physical, chemical, and photochemical processes. These processes influence the nature of the capture of the pollutants in a sink or reservoir, where they are transformed, immobilized or encapsulated /1/.

The industrialized society of the $20^{\text {th }}$ century has thus caused a radical change in the conditions of preservation and conservation of stone, and the atmospheric pollution associated with industrialization is currently a threat for the monumental cultural heritage. In fact, buildings and monuments act as repositories of airborne organic pollutants which accumulate at the surfaces in zones frequently soaked by rainwater but are not washed out. In these areas thick black crust deposits can be found which contribute to soiling of stone surfaces $/ 2 /$.

\section{SOURCES OF ORGANIC POLLUTANTS IN URBAN ENVIRONMENTS}

Organic compounds in the atmosphere arise from biotic (including anthropogenic components), abiotic (volcanic activity, lithospheric erosion) and extraterrestrial origin (meteorites). Only anthropogenic compounds will be considered in this review. 
The organic species present in the atmosphere comprise gases, lipids and carbonaceous (insoluble) matter. Among the gases, the short chain alkanes and alkenes, aldehydes, ketones and acids are frequent. They originate mainly from spillage of petroleum-derived products as well as from combustion processes. Apart from methane, which is the major biogenic organic gas, a minor amount of volatiles also evolves from microbial activity and odoriferous plants, as for instance, isoprene and monoterpenes $/ 3 /$.

Urban aerosols generally consist of a mixture of lipid materials emitted locally along the aged material that has been carried into the urban area by winds. Thus, the urban atmospheric environment contains many organic pollutants which are related to incomplete fuel combustion in domestic heating, industrial plants and vehicular exhausts /4/. In addition to organic compounds, carbonaceous matter (mainly black carbon) is common in urban environments. Table 1 shows the classes of compounds identified in aerosols and particulate matter $/ 5 /$.

Table 1

Classes of compounds identified in aerosols and particulate matter

\begin{tabular}{|c|c|c|c|}
\hline Compounds & Range $^{+}$ & Compounds & Range \\
\hline$n$-Alkanes & $\mathrm{C}_{7}-\mathrm{C}_{40}$ & Alkylnaphthoic acids & $\mathrm{C}_{11}-\mathrm{C}_{13}$ \\
\hline $\begin{array}{l}\text { Isoprenoid } \\
\text { hydrocarbons }\end{array}$ & $\mathrm{C}_{10}-\mathrm{C}_{20}$ & Alkylphenanthroic acids & $\mathrm{C}_{15}-\mathrm{C}_{17}$ \\
\hline Isoprenoid ketones & $\mathrm{C}_{10}-\mathrm{C}_{20}$ & Alkylcyclohexanes & $\mathrm{C}_{9}-\mathrm{C}_{20}$ \\
\hline Alkan-2-ones & $\mathrm{C}_{10}-\mathrm{C}_{32}$ & Diterpenoid derivatives & $\mathrm{C}_{16}-\mathrm{C}_{20}$ \\
\hline Alkanols & $\mathrm{C}_{11}-\mathrm{C}_{2 \mathrm{~B}}$ & Triterpenoid hydrocarbons & $\mathrm{C}_{27}-\mathrm{C}_{35}$ \\
\hline$n$-Fatty acids & $\mathrm{C}_{1}-\mathrm{C}_{34}$ & $\begin{array}{l}\text { Tricyclic terpane } \\
\text { hydrocarbons }\end{array}$ & $\mathrm{C}_{(1)}-\mathrm{C}_{2 y}$ \\
\hline $\begin{array}{l}\text { Hydroxy fatty } \\
\text { acids }\end{array}$ & $\mathrm{C}_{10}-\mathrm{C}_{26}$ & Steranes and diasteranes & $\mathrm{C}_{27}-\mathrm{C}_{29}$ \\
\hline $\begin{array}{l}\alpha, \omega \text {-Dicarboxylic } \\
\text { acids }\end{array}$ & $\mathrm{C}_{2}-\mathrm{C}_{2 \mathrm{~b}}$ & Unresolved hydrocarbons & $\mathrm{C}_{14}-\mathrm{C}_{31}$ \\
\hline Alkylbenzoic acids & $\mathrm{C}_{7}-\mathrm{C}_{9}$ & $\begin{array}{l}\text { Polycyclic } \\
\text { hydrocarbons }\end{array}$ & $\mathrm{C}_{10}-\mathrm{C}_{24}$ \\
\hline $\begin{array}{l}\text { Alkylbenzenedioic } \\
\text { acids }\end{array}$ & $\mathrm{C}_{R}-\mathrm{C}_{10}$ & $\begin{array}{l}\text { Oxygen-polycyclic aromatic } \\
\text { hydrocarbons }\end{array}$ & $\mathrm{C}_{10}-\mathrm{C}_{16}$ \\
\hline
\end{tabular}

${ }^{+}$Range denotes number of carbon atoms in the compounds 


\subsection{Hydrocarbons}

This class of compounds has been analysed in many urban areas $/ 6,7 /$. Typical $n$-alkane distributions range from $\mathrm{C}_{15}$ to $\mathrm{C}_{14}$ with no carbon number predominance (also termed carbon preference index or CPI). CPI is the sum of the odd-carbon number homologues over a specified range divided by the sum of the even-carbon-number homologues over the same range. This index is an indicator for evaluation of anthropogenic/biogenic contributors in aerosols. Since biogenic $n$-alkanes generally show a strong odd $C$-numbered predominance, their $\mathrm{CPl}$ values are high, whereas $n$-alkanes from petroleum, vehicular exhausts and lubricating oils have a CPI of 1 . Thus, the greater the anthropogenic contribution, the more closely the CPI approaches unity. As CPI of $n$-alkanes in urban aerosols is near 1 , it was concluded that fuels or partly uncombusted fuels do contribute to these aerosols $/ 8 /$.

Aerosols also contain isoprenoid hydrocarbons such as pristane (2,6,10,14-tetramethylpentadecane) and phytane (2,6,10,14-tetramethylhexadecane) which are diagenetic products of phytol and are not primary constituents of most terrestrial biota, thus confirming an origin from petroleum $/ 9 /$.

\subsection{Acids and ketones}

According to Simoneit and Mazurek /3/ these types of compounds originating from anthropogenic sources are usually only minor components of aerosols. The organic acids $\left(\mathrm{C}_{1}-\mathrm{C}_{10}\right)$ were detected in many urban aerosols and a similar distribution in motor exhaust from automobiles was found $/ 10 /$. Gasoline and diesel exhaust showed a dicarboxylic acid distribution $\left(\mathrm{C}_{2}-\mathrm{C}_{11}\right)$ similar to those of air samples /11/. Hence, the data indicate that vehicular emissions are the most important primary source of atmospheric acids.

\subsection{Triterpenoid hydrocarbons}

Biological markers are organic compounds present in the geosphere whose structures can be unambiguously linked to the structures of precursor compounds occurring in original source materials $/ 12 /$.

Hopane-type triterpanes are ubiquitous biological markers in fossil fuels and their precursors are widely distributed among organisms. Virtually all crude oils contain the hopane series, which are also found in aerosols. It has 
been reported that the distribution of the $17 \alpha(\mathrm{H}), 21 \beta(\mathrm{H})$-hopanes is essentially identical for auto and diesel exhausts, confirming these emissions as the major source of petroleum residues.in aerosols $/ 8 /$.

Gasoline and diesel fuel do not contain these triterpanes, but the same distribution is found in lubricating oils. This indicates that primarily lubricants adsorbed on particulates or as vapour microdroplets impart the molecular indicator signature of petroleum residues to vehicular emissions.

\subsection{Polycyclic aromatic hydrocarbons}

It is generally accepted that airborne polycyclic aromatic hydrocarbons are derived from combustion processes such as the burning of fossil fuel, forest fires and agricultural burning.

Lower polyaromatics (up to benzofluorene) are more abundant in the gas phase while higher polyaromatics are predominantly in the particulate fraction. The higher polyaromatics identified in aerosols are fluoranthene, pyrene, benz(a)anthracene, benzo(a)pyrene, dibenzanthracenes, benzo(ghi)perylene and coronene. The volatile polyaromatics are acenaphthene, biphenyl, fluorene, and some heterocyclic species such as dibenzofuran and dibenzothiophene $/ 3 /$.

\subsection{Carbonaceous matter}

The major components of carbonaceous species in ambient particles are organic carbon species and elemental (black) carbon. Black carbon and organic carbon aerosols are released from incomplete combustion of fuels. It has been found that typical aerosols contain 10 to $30 \%$ total carbon. Of this fraction, 20 to $50 \%$ is black carbon, less than 5 is carbonate, and the remainder is organic carbon $/ 3 /$. Black carbon is predominant in chimney smoke and engine exhaust.

Interestingly, it has been reported that carbonaceous particles consisting of uncombusted coal and oil, coal coke, and intermediates contribute significantly to the interaction with organic compounds. These particles appeared to behave not only as carriers of chemicals but also as gypsum nucleating agents $/ 13 /$.

A study of Sagebiel et al. /14/ illustrates the importance of diesel vehicles in the production of particulate emissions, as it was reported that 31 diesel vehicles whose age averaged 22 years showed average emissions of 944 
$\mathrm{mg} / \mathrm{km}$, with one vehicle emilting at a rate- $10,500 \mathrm{mg} / \mathrm{km}$. For comparison, emission rates of total particles were below $6 \mathrm{mg} / \mathrm{km}$ for most production catalyst vehicles. The particulate portion of diesel soot is almost exclusively carbon.

To investigate the possible contribution of diesel soot to organic pollutants and blackening of building stones in urban environments, diesel soot collected from the exhaust of a 10-year-old Sevillian public bus was analysed by Saiz-Jimenez /15/. The extract was a complex mixture of compounds, the $n$-alkanes being in the majority. Some of the identified classes of compounds are listed in Table 2, which agree with those reported in Table 1. In addition, many other compounds were identified up to a total of around 250, among which nitrogen- (e.g. quinolines), oxygen- (benzofurandiones, dibenzofurans), sulphur-heterocyclic compounds (dibenzothiophenes), phenols, alkan-2-ones, and alkanols, were also found.

\section{Table 2}

Main classes of compounds identified in diesel soot

\begin{tabular}{|l|l|l|l|}
\hline \multicolumn{1}{|c|}{ Compounds } & \multicolumn{1}{c|}{ Range $^{+}$} & \multicolumn{1}{c|}{ Compounds } & Range \\
\hline$n$-Alkanes & $\mathrm{C}_{14}-\mathrm{C}_{31}$ & Alkylnaphthalenes & $\mathrm{C}_{10}-\mathrm{C}_{17}$ \\
\hline$n$-Fatty acids & $\mathrm{C}_{6}-\mathrm{C}_{20}$ & Alkylfluorenes & $\mathrm{C}_{12}-\mathrm{C}_{15}$ \\
\hline $\begin{array}{l}\alpha, \omega \text {-Dicarboxylic } \\
\text { acids }\end{array}$ & $\mathrm{C}_{6}-\mathrm{C}_{11}$ & Alkylphenanthrenes & $\mathrm{C}_{14}-\mathrm{C}_{17}$ \\
\hline Alkylcyclohexanes & $\mathrm{C}_{16}-\mathrm{C}_{22}$ & Alkylbenzoic acids & $\mathrm{C}_{7}-\mathrm{C}_{10}$ \\
\hline Alkylbenzenes & $\mathrm{C}_{6}-\mathrm{C}_{21}$ & $\begin{array}{l}\text { Polycyclic aromatic } \\
\text { hydrocarbons }\end{array}$ & $\mathrm{C}_{12}-\mathrm{C}_{16}$ \\
\hline
\end{tabular}

' Range denotes number of carbon atoms in the compounds

\subsection{Sites investigated}

The organic compounds present in the black crusts collected from monuments located in three cities, Dublin (Ireland), Mechelen (Belgium), and Seville (Spain) were investigated. A sample corresponded to black gypsum crusts from the Custom House, an 18th century building in Dublin, constructed in 1791 with Portland limestone. In addition to damage to the fabric caused by the aggressive atmosphere of Dublin, and the damage caused by the corrosion of ferrous metals, the Custom House has suffered greatly from the effects of three major fires $/ 16 /$. Crusts were collected from 
the balustrade removed from the east front during the restoration works accomplished in 1988. The crusts were situated on the back part of the railing, in a sheltered and rain-protected site. The railing and small columns were eroded and free from the black crust, except on the underside of the railing.

The cathedral of Mechelen (13th-15th century), whose building materials and architecture were characteristic of many large historic buildings throughout Flanders, was also selected. The façades built of Balegem stone, a sandy limestone, are covered by a black gypsum crust, consisting mostly of fine-grained equidimensional crystals and a smaller amount of elongated crystals. The cathedral of Mechelen is situated on a straight line between Antwerp and Brussels and the heavily industrialized areas north of Brussels, and especially north of Antwerp, are some 15 and $25 \mathrm{~km}$ away, respectively. Therefore, Mechelen lies at the centre of one of the world's most polluted areas and downtown traffic passes around most of the cathedral /17/.

From the cathedral of Seville, the Prince Gate, constructed in 1887, was studied (Figure 1). The entrance to this gate is protected by a fence supported by a small limestone wall and pilasters, which were severely deteriorated due to black crust formation (Figure 2). This is related to the fact that one of the main Sevillian bus terminals, operating for more than twenty years, was just in front and less than $10 \mathrm{~m}$ from this wall. The exhaust gases and particulate matter heavily affected the limestone.

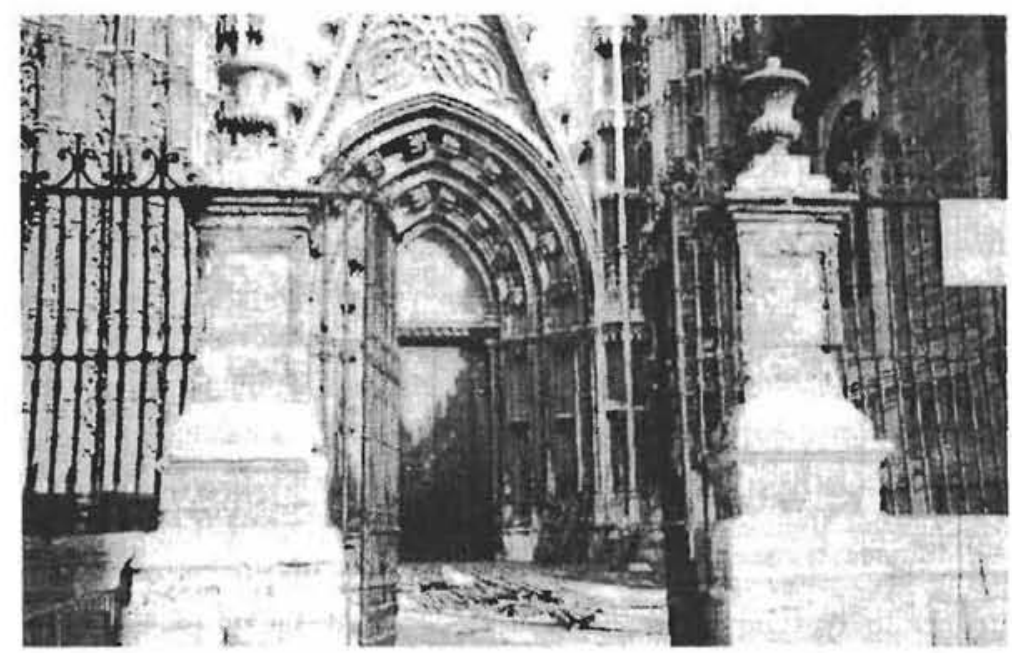

Fig. 1: Prince Gate, cathedral of Seville, constructed in 1887. 


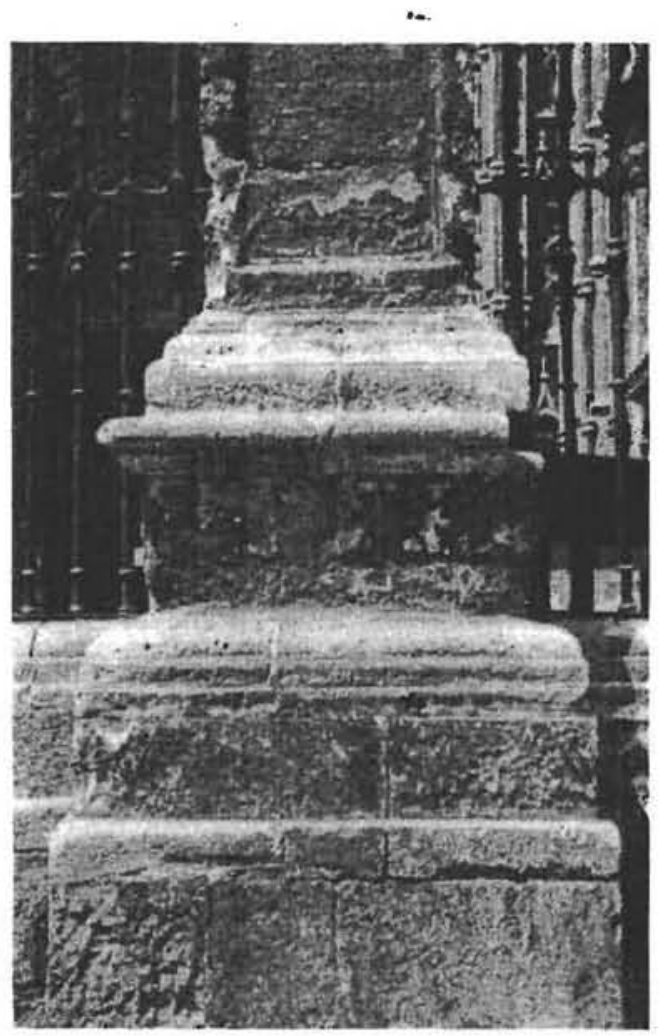

Fig. 2: Limestone wall and pilasters, severely deteriorated due to black crust formation.

\subsection{Solvent extraction of black crusts}

After extracting the samples with organic solvents, the extracts were methylated and deposited onto a ferromagnetic wire $\left(358^{\circ} \mathrm{C}\right)$ inserted in a pyrolysis unit coupled to a $\mathrm{gc} / \mathrm{ms}$ system. The solvent was removed before introduction into the pyrolysis unit. In this way good chromatograms, without interference from solvents, were obtained. The extractable lipid material consisted primarily of hydrocarbons and fatty acids (as methyl esters), represented by homologous series of $n$-alkanes ranging from $C_{13}$ to $C_{411}$, and $n$-fatty acids from $\mathrm{C}_{11}$ to $\mathrm{C}_{34}$ (Table 3 ). Furthermore, a few diterpenoids, triterpanes, polycyclic aromatic hydrocarbons, and dialkyl phthalates, were identified as major peaks. 
Table 3. Some series of organic compounds present in black crusts

\begin{tabular}{|l|c|c|c|c|c|c|c|}
\hline Location & $\begin{array}{c}n- \\
\text { Alkanes }\end{array}$ & $\mathrm{C}_{\max }$ & CPI & $\begin{array}{c}n \text {-Fatty } \\
\text { acids }\end{array}$ & $\mathrm{C}_{\max }$ & $\mathrm{CPI}$ & $\begin{array}{c}\text { Tri- } \\
\text { terpanes }\end{array}$ \\
\hline Dublin & $\mathrm{C}_{13}-\mathrm{C}_{35}$ & $\mathrm{C}_{29}$ & 1.3 & $\mathrm{C}_{10}-\mathrm{C}_{32}$ & $\mathrm{C}_{16}$ & 2.9 & $\mathrm{C}_{27}-\mathrm{C}_{34}$ \\
\hline Mechelen & $\mathrm{C}_{14}-\mathrm{C}_{40}$ & $\mathrm{C}_{29}$ & 1.7 & $\mathrm{C}_{12}-\mathrm{C}_{34}$ & $\mathrm{C}_{16}$ & 5.1 & $\mathrm{C}_{27}-\mathrm{C}_{34}$ \\
\hline Seville & $\mathrm{C}_{15}-\mathrm{C}_{40}$ & $\mathrm{C}_{31}$ & 1.0 & $\mathrm{C}_{10}-\mathrm{C}_{34}$ & $\mathrm{C}_{22}$ & 1.9 & $\mathrm{C}_{27}-\mathrm{C}_{35}$ \\
\hline
\end{tabular}

The range of $n$-alkanes found in black crusts is determined by the analytical procedure. This is due to the technical difficulty associated with the analysis of high molecular weight alkanes (typically $>n-C_{35}$ ), which are less amenable to chromatographic analysis in conventional capillary gc. It is considered that in the black crusts, in a similar way to oils and derivatives, the $n$-alkane range could be greater than those found in gc studies.

For investigating sources of homologous series of $n$-alkanes, CPI was used. CPI of $n$-alkanes for each sample ranged from 1.0 to 1.7 , denoting an exclusive contribution of petroleum derivatives for the Seville crust, and progressive inputs of alkanes of biological origin in the Dublin and Mechelen crusts.

The contribution of the major urban air pollution sources can be diagnosed by using organic molecular marker techniques /4/. The source of the hydrocarbons is confirmed by the suite of biomarkers found in the black crusts, as for example the triterpanes, and the hump or unresolved complex mixture (UCM) in the chromatograms of the Irish and Spanish extracts. In fact, these samples exhibited a broad envelope of UCM components ranging approximately from $n-\mathrm{C}_{16}$ to $n-\mathrm{C}_{38}$ alkanes for the Spanish and $n-\mathrm{C}_{18}$ to $n-\mathrm{C}_{32}$ for the Irish extract, which have been reported to be composed of highly branched and cyclic hydrocarbons, and ascribed to lubricating oil /8/ and petroleum $/ 18 /$.

According to Simoneit /19/ petroleum contains only minor amounts of long-chain fatty acids. However, the distribution of $n$-fatty acids in diesel engine exhaust and in lubricating is similar to those reported for the crusts. From all the three crust extracts, only the CPI for fatty acids in the Spanish sample agree with those of vehicular emissions, whereas it appears that the fatty acid fractions could have a biogenic origin in the Irish and Belgian extracts.

Petroleum biomarkers are compounds utilized for defining both the fossil origin and the geological source of the petroleum residues $120 \%$. In fact, as 
crude oils usually contain tricyclic terpanes and hopanes, triterpanes have been proposed as sensitive molecular markers of petroleum pollution. The triterpanes of the black crusts are composed of predominantly the $17 \alpha(\mathrm{H}), 21 \beta(\mathrm{H})$-hopane series, which is of a petroleum origin. Tricyclic terpanes make them further possible indicators of petroleum. In addition, series of steranes were also present (Table 4).

Table 4

Triterpanes and steranes identified in European black crusts

Tricyclic terpanes

$\mathrm{C}_{23}$ tricyclic terpane

$\mathrm{C}_{24}$ tricyclic terpane

$\mathrm{C}_{25}$ tricyclic terpane

$\mathrm{C}_{26}$ tricyclic terpane

$\mathrm{C}_{27}$ tricyclic terpane

$\mathrm{C}_{2 \mathrm{x}}$ tricyclic terpane

$\mathrm{C}_{2 \text {, }}$ tricyclic terpane

\section{Steranes}

$5 \alpha(\mathrm{H}), 14 \beta(\mathrm{H})$-cholestane

24-methyl-5 $\alpha(\mathrm{H}), 14 \beta(\mathrm{H}), 17 \beta(\mathrm{H})$-cholestane

24-ethyl-5 $\alpha(\mathrm{H}), 14 \beta(\mathrm{H}), 17 ß(\mathrm{H})$-cholestane

Hopanes

$18 \alpha(\mathrm{H})-22,29,30$-trisnorhopane (Ts)

$17 \alpha(\mathrm{H})-22,29,30$-trisnorhopane (Tn')

$17 \alpha(\mathrm{H}), 21 \beta(\mathrm{H})-30$-norhopane

$17 \beta(\mathrm{H}), 21 \alpha(\mathrm{H})$-30-normoretane

$17 \alpha(\mathrm{H}), 21 \beta(\mathrm{H})$-hopane

$17 \beta(\mathrm{H}), 21 \alpha(\mathrm{H})$-moretane

$17 \alpha(\mathrm{H}), 21 \beta(\mathrm{H})$-homohopane $22 \mathrm{~S}$

$17 \alpha(\mathrm{H}), 21 \beta(\mathrm{H})$-homohopane $22 \mathrm{R}$

$17 \alpha(\mathrm{H}), 2 \mathrm{I} \beta(\mathrm{H})$-bishomohopane $22 \mathrm{~S}$

$17 \alpha(\mathrm{H}), 21 \beta(\mathrm{H})$-bishomohopane $22 \mathrm{R}$

$17 \alpha(\mathrm{H}), 21 \beta(\mathrm{H})$-trishomohopane 22S

$17 \alpha(\mathrm{H}), 21 \beta(\mathrm{H})$-trishomohopane $22 \mathrm{R}$

$17 \alpha(\mathrm{H}), 21 \beta(\mathrm{H})$-tetraquishomohopane 22S

$17 \alpha(\mathrm{H}), 21 \beta(\mathrm{H})$-tetraquishomohopane $22 \mathrm{R}$

$17 \alpha(\mathrm{H}), 21 \beta(\mathrm{H})$-pentaquishomohopane $22 \mathrm{~S}$

$17 \alpha(\mathrm{H}), 21 \beta(\mathrm{H})$-pentaquishomohopane $22 \mathrm{R}$ 
The hopanes are relatively easy to detect by using $\mathrm{gc} / \mathrm{ms}$ and ion monitoring since two major fragment ions, m/z 191 and $\mathrm{m} / \mathrm{z} 148+\mathrm{R}$, are formed from the parent ion in the ion source of the mass spectrometer. Interestingly, the pattern of the biomarkers found in black crusts is similar to those reported for crude oil / 12 , automobile and diesel engine exhausts $/ 8 /$.

All the compounds identified in black crusts are found in vehicular emissions, diesel fuel, and lubricating oil /8/. The origin of those encountered in the Sevillian black crust can be ascribed directly to the vehicular exhausts originated by idle engines in the bus stop.

Diterpenoids are regarded as characteristic molecular markers for conifer resins (i.e. methyl dehydroabietate), and retene is an incomplete combustion product of compounds with the abietane skeleton $/ 21 /$. These compounds are frequent in cities in which residential wood combustion is widely used, and therefore could only be observed in Dublin and Mechelen but not in Seville.

Polycyclic aromatic hydrocarbons are the result of combustion-generated airborne particulate matter, and have been identified, among other sources, in smoke particles from plant burning $/ 21 /$ and diesel engine soot $/ 22 /$. It is wellknown that organic compounds adsorbed onto the particulate phase of diesel exhaust possess direct-acting mutagenicity and can be accounted for by polycyclic aromatic hydrocarbons /23/. Polycyclic aromatic hydrocarbon mixtures encountered in crust extracts are complex because of the presence of alkyl-substituted compounds, as well as the numerous isomeric parent compounds. Generally, compounds from two to six aromatic rings are widely distributed in the three crust extracts, particularly in the Irish one. In addition, ketones, sulphur and nitrogen-substituted compounds were identified.

Studies on the organic composition of black crusts have been carried out by other authors with similar results. Nord and Ericsson $/ 24 /$ found $n-C_{\text {, }}$ to $n$ $\mathrm{C}_{30}$ alkanes, $\mathrm{PAH}$ from three to seven aromatic rings, and some nitrogen- and sulphur-containing polycyclic aromatic species as main compounds of the black crusts from a church in Stockholm. In the black crusts from historic monuments in Dresden, Machill et al. $/ 25 /$ found $n-\mathrm{C}_{14}$ to $n-\mathrm{C}_{29}$ alkanes, $n$ $\mathrm{C}_{10}$ to $n$ - $\mathrm{C}_{25}$ alkanols, $n$-fatty acids from $\mathrm{C}_{3}$ to $\mathrm{C}_{24}, \alpha, \omega$-dicarboxylic acids from $\mathrm{C}_{2}$ to $\mathrm{C}_{1}$, some hydroxyacids and aromatic acids, $\mathrm{PAH}$ from two to five aromatic rings, sulphur-, and oxygen-containing polycyclic aromatic species, and a few diterpenoids and carbohydrate derivatives.

All classes of compounds shown in Tables 3 and 4 have been previously identified in gas phase, aerosols, and particulate matter in urban atmospheres. This is of interest as Grimalt et al. /26/ reported the close similarity between 
the organic composition of black crusts from the Holy Family church (Barcelona, Spain), and airborne particulates, collected by glass fibre filtration, and gas-phase organic compounds, obtained by polyurethane foam adsorption. These facts and the finding of carbonaceous particles entrapped in the voids of gypsum crystals demonstrated that the organic compounds present in the black crusts, covering the building stones in urban environments, are the result of a direct input of air pollutants, the buildings acting as non-selective surfaces passively entrapping all deposited aerosols and particulate matter, from whose analysis a source can be traced.

\section{CONCLUSIONS}

From the data, it was concluded that the black crusts from different European monuments and buildings contain molecular markers that are characteristic of petroleum derivatives. The overprint of some biogenic components of aerosols over petroleum components from anthropogenic emissions (mainly vehicular) can be illustrated by the dominance of hydrocarbons around $n-\mathrm{C}_{29}$ (plant waxes) and fatty acids in the range $n-\mathrm{C}_{12^{-}}$ $\mathrm{C}_{10}$ (microorganisms and plant waxes). Accordingly, the black crusts coating the surfaces of building materials located in urban environments are constituted by a suite of all kind of organic compounds present in aerosols and particulate matter, which are transferred by dry and/or wet deposition. The composition of each crust is governed by the composition of the particular airborne pollutants in the area, but is mainly derived from vehicular emissions, diesel engines having a strong influence. Finally, it is clear that the exposed building materials act as a non-selective surface, passively entrapping all deposited airborne particulate matter and organic compounds which obviously modifies the composition of the materials present in the stone surface.

\section{ACKNOWLEDGEMENTS}

This work was supported by the European Commission, project EVK4CT2000-00029, and the Spanish Ministry of Science and Technology, project BTE2001-1277. 


\section{REFERENEES}

1. W.H. Schroeder and D.A. Lane, Environ. Sci. Technol. 22, 240 (1988).

2. C. Saiz-Jimenez, Atmos. Environ. 27B, 77 (1993).

3. B.R.T. Simoneit and M.A. Mazurek, CRC Crit. Rev. Environ. Control. 11, 219 (1981).

4. G.R. Cass, Trends Anal. Chem. 17, 356-366 (1998).

5. C. Saiz-Jimenez, Aerobiologia, 11, 161 (1995).

6. B.M. Broderick and I.S. Marnane, Atmos. Environ. 36, 975 (2002).

7. M.F. Mohamed et al., Chemosphere 47, 863 (2002).

8. B.R.T. Simoneit, Int. J. Environ. Anal. Chem. 22, 203 (1985).

9. B.R.T. Simoneit, Sci. Total Environ. 36, 61 (1984).

10. K. Kawamura et al., Environ. Sci. Technol. 19, 1082 (1985).

11. K. Kawamura and I.R. Kaplan, Environ. Sci. Technol. 21, 105 (1987)

12. R.P. Philp, Mass Spectrom. Rev. 4, 1 (1985).

13. M. Del Monte et al., Sci. Total Environ. 36, 369 (1984).

14. J.C. Sagebiel et al., Environ. Sci. Technol. 31, 75 (1997).

15. C. Saiz-Jimenez, Humic Substances in the Global Environment and Implications on Human Health, N. Senesi and T.M. Miano (Eds.), p. 71, Elsevier, Amsterdam, 1994.

16. C. Saiz-Jimenez, Science, Technology and European Cultural Heritage, N.S. Baer et al. (Eds.), p. 523, Butterworth-Heinemann, Oxford, 1991.

17. B.O. Fobe et al., Environ. Sci. Technol. 29, 1691 (1995).

18. M.A. Gough and S.J. Rowland, Nature 344, 648 (1990).

19. B.R.T. Simoneit, Int. J. Environ. Anal. Chem. 23, 207 (1986).

20. B.R.T. Simoneit et al., Atmos. Environ. 22, 983 (1988).

21. L.J. Standley and B.R.T. Simoneit, Environ. Sci. Technol. 21, 163 (1987).

22. M-L. Yu and R.A. Hites, Anal. Chem. 53, 951 (1981).

23. J.M. Bayona et al., Environ. Sci. Technol. 22, 1440 (1988).

24. A.G. Nord and T. Ericsson, Stud. Conserv. 38, 25 (1993).

25. S. Machill et al., Org. Geochem. 27, 79 (1997).

26. J.O. Grimalt et al., Organic Geochemistry. Advances and Applications in the Natural Environment, D.A.C. Manning (Ed.), p. 513, Manchester University Press, Manchester, 1991. 